\title{
A preliminary study on the occurrence of microscopic asexual fungi associated with bird nests in Brazilian semi-arid
}

\section{Conceição LB ${ }^{1}$ and Marques MFO'}

\author{
${ }^{1}$ Universidade do Estado da Bahia, Departamento de Educação, Campus VII, Laboratório de Biologia Molecular e \\ Fungos. Rod. Lomanto Júnior, Br 407, Km 127, 48970-000, Senhor do Bonfim, BA.
}

Conceição LB, Marques MFO 2015 - A preliminary study on the occurrence of microscopic asexual fungi associated with bird nests in Brazilian semi-arid. Mycosphere 6(3), 274-279, Doi $10.5943 /$ mycosphere/6/3/5

\begin{abstract}
Bird nests are made up of twigs, leaves and bark, among other things, all substrates that are decomposed by fungi. Thus, the richness of microscopic asexual fungi associated with the plant substrates that make up the bird nests in a fragment of the semi-deciduous seasonal forest in the "Serra da Maravilha", Senhor do Bonfim, Bahia, Brazil was studied. The plant substrates were collected between February to July 2014. Forty-four species of microscopic asexual fungi were identified distributed in 36 genera, associated with the decomposition of 11 birds' nests. Among the species cataloged, Actinocladium rhodosporium, Alternaria alternata, Cryptophiale kakombensis, Ellisembia adscendens, Gyrothrix circinata, Gyrothrix microsperma, Tetraploa aristata, Thozetella cristata and Torula herbarum were found throughout the study, while the other species were found sporadically. Dendryphion cubense constitutes a new record for South America, Endophragmiella valdiviana represents a new record for Brazil and Uberispora heteroseptata is a new record for Bahia.
\end{abstract}

Keywords - biodiversity - birds - conidial fungi - mycota

\section{Introduction}

Fungi form an extremely abundant and morphologically diverse kingdom, which includes saprobic, symbiont and parasitic species (Heredia et al. 2000). Microscopic asexual fungi are pioneers in decomposing plant materials since they have an enzymatic framework capable of breaking down the distinct substances found in these substrates (Dix \& Webster 1995).

Estimates of the number of fungi on the planet, range up to 1.5 to 5.1 million species (Hawksworth 1991, Blackwell 2011), and there are many little or never explored environments. These studies suggest a great diversity of yet unknown fungi species, which are most likely in the tropical ecosystems. Thus, little explored micro-habitats like bird nests make an ideal environment for fungal colonization since they have a diversified plant composition.

This work aimed to estimate the richness of microscopic asexual fungi associated with the plant substrates which make up bird nests in a fragment of the semi-deciduous seasonal forest in the "Serra na Maravilha", Senhor do Bonfim, Bahia, Brazil.

\section{Materials and Methods}

The "Serra de Jacobina", located in the Meridional Sertão Depression Eco-Region (Velloso 
et al. 2002), is formed by a mountainous complex that extends $200 \mathrm{~km}$ from north to south, an extension more to the northeast of the "Chapada Diamantina", state of Bahia, Brazil. In this complex, the "Serra da Maravilha" pertains to the city of Senhor do Bonfim, with an altitude that varies from $700 \mathrm{~m}$ to $1000 \mathrm{~m}$ and vegetation typical of the Caatinga being less expressive, being associated with a Semi-deciduous Seasonal Forest (Castelletti et al. 2003).

Sampling expeditions were carried out in a fragment of the semi-deciduous seasonal forest in the "Serra da Maravilha", from February to July 2014. In the first expedition, demarcation of abandoned nests took place randomly as they were found, and from the composition and morphology of the nests the ethnozoological identification of them was carried out by a native of the area, who indicated the common names of the birds. These common names were compared with a list of local bird-fauna to arrive at the scientific names (Table 1).

Table 1 Number of nests studied from each bird species and substrate composition.

\begin{tabular}{|c|c|c|}
\hline Birds/ Common name & No. of nests collected & Composition \\
\hline $\begin{array}{l}\text { Arremon taciturnus (Hermann 1783), pectoral } \\
\text { sparrow }\end{array}$ & 1 & $\begin{array}{l}\text { Straw of Syagrus coronata } \\
\text { (Martius) Beccari and undetermined } \\
\text { angiosperm twigs. }\end{array}$ \\
\hline $\begin{array}{l}\text { Cacicus cela (Linnaeus 1758), yellow-rumped } \\
\text { cacique }\end{array}$ & 1 & $\begin{array}{l}\text { Poaceae leaves and undetermined } \\
\text { angiosperm twigs. }\end{array}$ \\
\hline $\begin{array}{l}\text { Leptotila verreauxi Bonaparte } 1855 \text {, white- } \\
\text { tipped dove }\end{array}$ & 1 & $\begin{array}{l}\text { Barks, twigs and leaves from } \\
\text { undetermined angiosperms. }\end{array}$ \\
\hline $\begin{array}{l}\text { Sporophila nigricollis (Vieillot 1823), yellow- } \\
\text { bellied seedeater }\end{array}$ & 1 & $\begin{array}{l}\text { Leaves and fine roots from } \\
\text { undetermined angiosperms. }\end{array}$ \\
\hline Taraba major (Vieillot 1816), great antshrike & 1 & $\begin{array}{l}\text { Poaceae leaves and undetermined } \\
\text { angiosperm twigs and leaves. }\end{array}$ \\
\hline $\begin{array}{l}\text { Turdus rufiventris Vieillot } 1818 \text {, rufous-bellied } \\
\text { thrush }\end{array}$ & 5 & $\begin{array}{l}\text { Petioles, twigs, leaves and fine roots } \\
\text { from undetermined angiosperms } \\
\text { and bryophytes. }\end{array}$ \\
\hline Undetermined, "tuti" & 1 & $\begin{array}{lll}\text { Leaves and roots from } \\
\text { undetermined angiosperms. }\end{array}$ \\
\hline
\end{tabular}

Plant samples from the abandoned nests were collected every two months and placed in sterile plastic bags. Each sample filled the volume of plant material necessary for assembling a humid chamber in Petri dishes $(150 \times 18 \mathrm{~mm})$. The samples were taken to the "Laboratório de Biologia Molecular e Fungos" the Universidade do Estado da Bahia, Departamento de Educação, Campus VII, for processing.

At the laboratory, the material went through a modified washing, drying and incubation process created by Castañeda-Ruiz (2005), which consisted of washing the material in running water for around 20 minutes, drying the materials on a paper towel at room temperature for around 20 minutes and then incubation in Petri dishes containing moistened filter paper, followed by packing the chambers in Styrofoam boxes, covered once again with moist paper towels. After incubation and processing, the asexual microscopic fungal reproduction structures were transferred to permanent slides containing PVL (polyvinyl alcohol + lactophenol). Identification was based on classic taxonomy with the help of a basic and specialized bibliography. The sample specimens were deposited in the Herbarium at the Universidade do Estado da Bahia (HUNEB - Senhor do Bonfim Collection).

Unfortunately, by the second collecting three Turdus rufiventris nests, one A. taciturnus and one undetermined ("Tuti") had been lost, while at the third collecting there was a loss of a $S$. nigricollis nest.

\section{Results and Discussion}

From the 11 nests, 44 species of microscopic asexual fungi were identified distributed in 36 genera. The greatest richness of species was recorded in the first sampling ( 32 species) followed by the second sampling (21 species) and the third sampling (19 species) (Table 2). The decreasing 
number of fungal species found during the sampling is probably explained by the decreasing number of nests collected at each sampling. The decreasing number of nests sampled in the collections happened mostly due to anthropic actions, through fallen trees in the study area as well as through heavy rains that ended up knocking them down.

The Turdus rufiventris nests recorded the greatest richness of microscopic asexual fungi, with 28 species, followed by the Taraba major nest with 14 species, while the A. taciturnus nest had only one species of fungus recorded. Such differences could be associated with the composition of the bird nests since the Turdus rufiventris and Taraba major nests showed different substrates and that of the A. taciturnus had only two substrates in its composition (Table 1).

Among the species found, Actinocladium rhodosporium, Alternaria alternata, Cryptophiale kakombensis, Ellisembia adscendens, Gyrothrix circinata, Gyrothrix microsperma, Tetraploa aristata, Thozetella cristata and Torula herbarum occurred throughout the study, while the other species were found sporadically.

Most of the species found in the study are known in Brazil as associated with leaf litter materials (Marques et al. 2007, 2008, Barbosa et al. 2008, Cruz \& Gusmão 2009, Almeida et al. 2012), showing that the substrates that compose the nest as well as their structures, favor colonization by microscopic asexual fungi, which was expected due to the leaf litter serving as a source of material that makes up the nests.

Dendryphion cubense constitutes a new record for South America, being previously referenced in Cuba (Matsushima 1987), Thailand (Kodsueb et al. 2008) and Taiwan (Chen \& Tzean 2009). Endophragmiella valdiviana represents a new record for Brazil, being previously cataloged in Chile (Ellis 1963), New Zealand (Hughes 1979), Japan (Matsushima 1983), China (Wu \& Zhuang 2005), Spain (Silvera-Simón et al. 2009) and Mexico (Arias et al. 2010, Abarca et al. 2013) and Uberispora heteroseptata constitutes a new record for Bahia, being previously registered in Brazil in São Paulo (Silva \& Grandi 2008) and Pernambuco (Cruz \& Gusmão 2009) (Fig. 1).
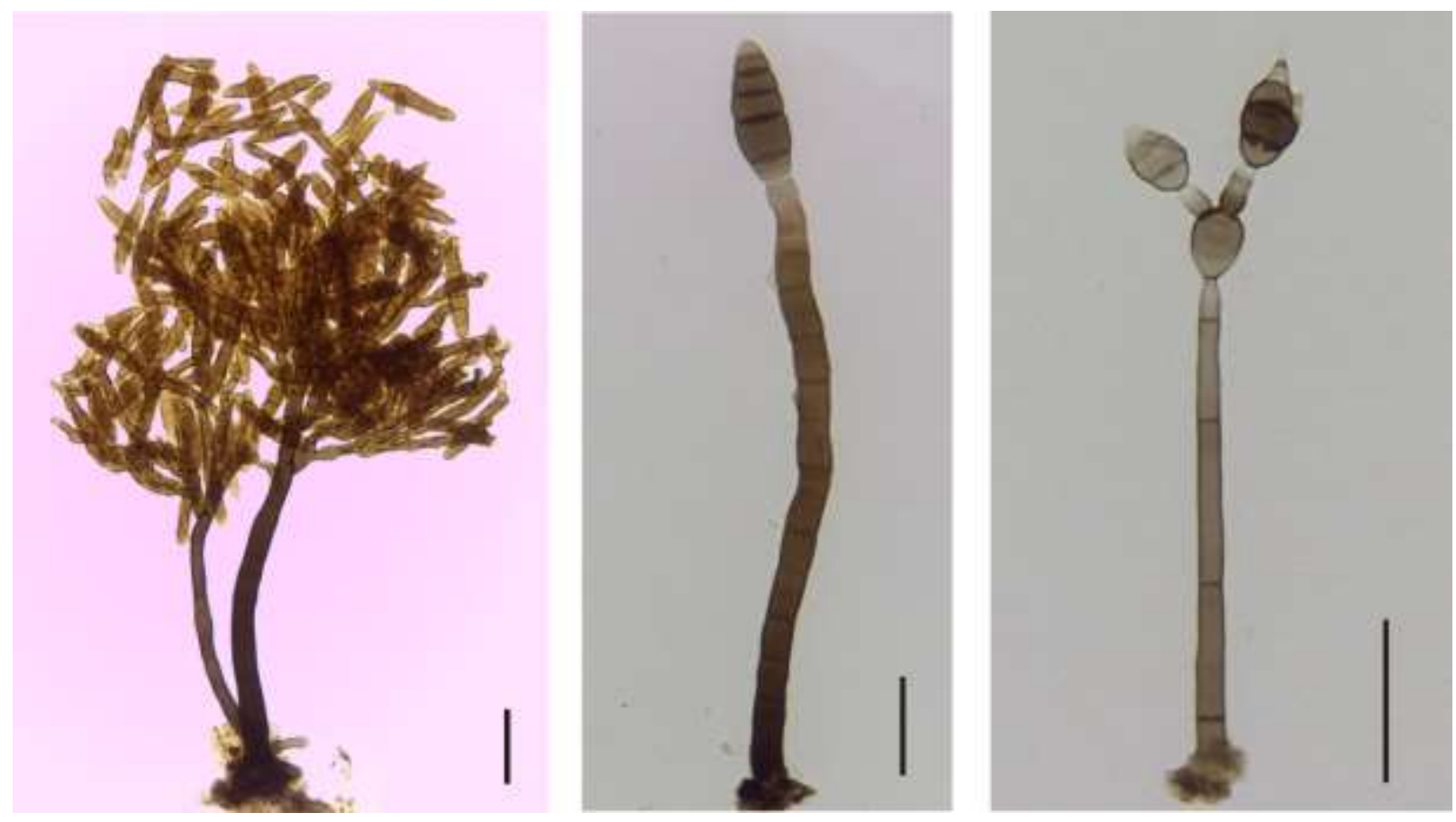

Fig. 1 - General aspect of the new records of microscopic asexual fungi species associates with bird nests in a fragment of the seasonal forest in the "Serra da Maravilha", Senhor do Bonfim, Bahia. A. Dendryphion cubense B. Endophragmiella valdiviana. C. Uberispora heteroseptata $($ Bars $=30 \mu \mathrm{m})$. 
Table 2 Richness of microscopic asexual fungi associated with bird nests in a fragment of the "Serra da Maravilha", Senhor do Bonfim, Bahia, Brasil ( $\mathrm{Tr}=$ Turdus rufiventris; Lv = Leptotila verreauxi $; \mathrm{At}=$ Arremon taciturnus $; \mathrm{Sn}=$ Sporophila nigricollis $; \mathrm{Tm}=$ Taraba major $; \mathrm{Cc}=$ Cacicus cela and In = sp. undetermined; *New record for South America; **New record for Brazil; *** New record for Bahia).

\begin{tabular}{|c|c|c|c|c|}
\hline Species & $\begin{array}{l}\text { Sampling } \\
1\end{array}$ & $\begin{array}{l}\text { Sampling } \\
2\end{array}$ & $\begin{array}{l}\text { Sampling } \\
3\end{array}$ & Associated nest \\
\hline Actinocladium rhodosporium Ehrenb. & $\mathrm{x}$ & $\mathrm{x}$ & $\mathrm{x}$ & Tr e Lv \\
\hline Alternaria alternata (Fr.) Keissl. & $\mathrm{x}$ & $\mathrm{x}$ & $\mathrm{x}$ & Tr, Lv, Sn e Tm \\
\hline Beltrania rhombica Penz. & $\mathrm{x}$ & $\mathrm{x}$ & & $\operatorname{Tr}$ \\
\hline Beltraniella portoricensis (F. Stevens) Piroz. \& S.D. Patil & & & $\mathrm{x}$ & $\operatorname{Tr}$ \\
\hline Brachysporiella gayana Bat. & & $\mathrm{x}$ & & $\mathrm{Lv}$ \\
\hline Chalara alabamensis Morgan-Jones \& E.G. Ingram & $\mathrm{x}$ & & $\mathrm{x}$ & $\operatorname{Tr}$ \\
\hline Circinotrichum olivaceum (Speg.) Piroz. & & $\mathrm{x}$ & & $\operatorname{Tr}$ \\
\hline Cryptophiale kakombensis Piroz. & $\mathrm{x}$ & $\mathrm{x}$ & $\mathrm{x}$ & $\operatorname{Tr}$ \\
\hline Curvularia eragrostidis (Henn.) J.A. Mey. & $\mathrm{x}$ & & & Tr e Tm \\
\hline *Dendryphion cubense Matsush. & $\mathrm{x}$ & & & $\operatorname{Tr}$ \\
\hline Dictyochaeta triseptata (Matsush.) R.F. Castañeda & $\mathrm{x}$ & & & Tr e In \\
\hline Ellisembia adscendens (Berk.) Subram. & $\mathrm{x}$ & $\mathrm{x}$ & $\mathrm{x}$ & Tr e Lv \\
\hline **Endophragmiella valdiviana (Speg.) S. Hughes & & & $\mathrm{x}$ & $\mathrm{Cc}$ \\
\hline Fusariella atrovirens (Berk.) Sacc. & $\mathrm{x}$ & & & $\mathrm{Tm}$ \\
\hline Gyrothrix circinata (Berk. \& M.A. Curtis) S. Hughes & $\mathrm{x}$ & $\mathrm{x}$ & $\mathrm{x}$ & $\mathrm{Tr}, \mathrm{Tm}$ e Cc \\
\hline Gyrothrix microsperma (Höhn.) Piroz. & $\mathrm{x}$ & $\mathrm{x}$ & $\mathrm{x}$ & $\operatorname{Tr}$ \\
\hline Gyrothrix podosperma (Corda) Rabenh. & $\mathrm{x}$ & & & $\operatorname{Tr}$ \\
\hline Gyrothrix ramosa Zucconi \& Onofri & & & $\mathrm{x}$ & $\mathrm{Tm}$ \\
\hline Hermatomyces sphaericus (Sacc.) S. Hughes & $\mathrm{x}$ & $\mathrm{x}$ & & Lv \\
\hline Junewangia globulosa (Tóth) W.A. Baker \& Morgan-Jones & $\mathrm{x}$ & & & $\mathrm{Lv}$ \\
\hline Memnoniella subsimplex (Cooke) Deighton & $\mathrm{x}$ & & & In \\
\hline Menisporopsis theobromae $\mathrm{S}$. Hughes & $\mathrm{x}$ & & $\mathrm{x}$ & Cc e In \\
\hline Periconia byssoides Pers. & $\mathrm{x}$ & & $\mathrm{x}$ & $\begin{array}{l}\text { Tr, Lv, Sn, Tm e } \\
\text { Cc }\end{array}$ \\
\hline Periconia macrospinosa Lefebvre \& Aar.G. Johnson & $\mathrm{x}$ & & & $\mathrm{Sn}$ \\
\hline Periconia minutissima Corda & $\mathrm{x}$ & & & Tr, Tm e In \\
\hline Phaeoisaria infrafertilis B. Sutton \& Hodges & & $\mathrm{x}$ & & $\operatorname{Tr}$ \\
\hline Pithomyces chartarum (Berk. \& M.A. Curtis) M.B. Ellis & $\mathrm{x}$ & & & $\begin{array}{l}\text { Tr, Lv, Sn, Tm e } \\
\text { In }\end{array}$ \\
\hline Pithomyces maydicus (Sacc.) M.B. Ellis & $\mathrm{x}$ & $\mathrm{x}$ & & $\operatorname{Tr}$ e Sn \\
\hline $\begin{array}{l}\text { Pseudoacrodictys viridescens (B. Sutton \& Alcorn) W.A. Baker \& } \\
\text { Morgan-Jones }\end{array}$ & & $\mathrm{x}$ & & $\operatorname{Tr}$ \\
\hline Satchmopsis brasiliensis B. Sutton \& Hodges & $\mathrm{x}$ & $\mathrm{x}$ & & $\operatorname{Tr}$ \\
\hline Spegazzinia deightonii (S. Hughes) Subram. & & $\mathrm{x}$ & & $\mathrm{Tm}$ \\
\hline Spegazzinia tessarthra (Berk. \& M.A. Curtis) Sacc. & $\mathrm{x}$ & $\mathrm{x}$ & & Sn e Tm \\
\hline Sporendocladia foliicola (P.M. Kirk) M.J. Wingf. & & & $\mathrm{x}$ & $\mathrm{Lv}$ \\
\hline Sporidesmiella aspera Kuthub. \& Nawawi & & $\mathrm{x}$ & & $\operatorname{Tr}$ \\
\hline Sporidesmiella hyalosperma (Corda) P.M. Kirk & $\mathrm{x}$ & $\mathrm{x}$ & & $\operatorname{Tr}$ e $\mathrm{Cc}$ \\
\hline Stachybotrys nephrospora Hansf. & & & $\mathrm{x}$ & $\mathrm{Tm}$ \\
\hline Tetraploa aristata Berk. \& Broome & $\mathrm{x}$ & $\mathrm{x}$ & $\mathrm{x}$ & Lv e Tm \\
\hline Thozetella cristata Piroz. \& Hodges & $\mathrm{x}$ & $\mathrm{x}$ & $\mathrm{x}$ & $\operatorname{Tr}$ e Lv \\
\hline Torula herbarum (Pers.) Link & $\mathrm{x}$ & $\mathrm{x}$ & $\mathrm{x}$ & $\mathrm{Tr}, \mathrm{Sn}, \mathrm{Tm}$ e Cc \\
\hline ***Uberispora heteroseptata R.F. Castañeda, Guarro \& Cano & $\mathrm{x}$ & & & $\operatorname{Tr}$ \\
\hline Umbellidion radulans $\mathrm{B}$. Sutton \& Hodges & & & $\mathrm{x}$ & $\operatorname{Tr}$ \\
\hline Veronaea coprophila (Subram. \& Lodha) M.B. Ellis & $\mathrm{x}$ & & $\mathrm{x}$ & Tr e Tm \\
\hline Volutella minima Höhn. & $\mathrm{x}$ & & & In \\
\hline Zygosporium minus S. Hughes & $\mathrm{x}$ & & & At \\
\hline
\end{tabular}




\section{Acknowledgement}

The authors thank the PPBIO/CNPq (Biodiversity Research Program in Semiarid Regions, proc. 558317/2009-0).

\section{References}

Abarca GH, Mena-Portales J, Mercado-Sierra AM, Columna MF. 2013 - Nuevos registros de hongos anamorfos tropicales asociados a restos vegetales para México. Revista Mexicana de Micología 37, 69-81.

Almeida DAC, Barbosa FR, Gusmão LFP. 2012 - Alguns fungos conidiais aquaticos-facultativos do bioma Caatinga. Acta Botanica Brasilica 26(4), 924-932.

Arias RM, Heredia G, Mena-Portales J. 2010 - Adiciones al conocimiento de la diversidad de los hongos anamorfos del bosque mesófilo de montaña del estado de Veracruz III. Acta Botánica Mexicana 90, 19-42.

Barbosa FR, Gusmão LFP, Barbosa FF. 2008 - Fungos anamórficos (Hyphomycetes) no Semiárido do Estado da Bahia, Brasil. Acta Botanica Brasilica 22(1), 29-36.

Blackwell M. 2011 - The Fungi: 1, 2, 3 ...5.1 million species? American Journal of Botany 98(3), 426-438.

Castañeda-Ruiz RF. 2005 - Metodología en el estudio de los hongos anamorfos. In: Anais do V Congresso Latino Americano de Micologia, Brasília, pp. 182-183.

Castelletti CHM, Santos AMM, Tabarelli M, Silva JMC. 2003 - Quanto ainda resta da Caatinga? Uma estimativa preliminar. In: Leal IR, Tabarelli M, Silva JMC (eds) Ecologia e conservação da Caatinga Editora Universitária, Universidade Federal de Pernambuco, Recife, pp. 719734.

Chen JL, Tzean S. 2009 - Some Hyphomycetes (Deuteromycotina) Beltraniella and its allies in Taiwan. Fungal Science 24, 1-14.

Cruz ACR, Gusmão LFP. 2009 - Fungos conidiais na Caatinga: espécies associadas ao folhedo. Acta botanica brasilica 23(4), 999-1012.

Dix NJ, Webster J. 1995 - Fungal Ecology. Chapman and Hall, London.

Ellis MB. 1963 - Dematiaceous Hyphomycetes. IV. Mycological Papers 87, 1-42.

Hawksworth DL. 1991 - The fungal dimension of biodiversity: magnitude, significance and conservation. Mycological Research 95, 641-655.

Heredia G, Arias RM, Estebanez MR. 2000 - Contribución al conocimiento de los hongos Hyphomycetes de México. Acta Botánica Mexicana 51, 39-51.

Hughes SJ. 1979 - Relocation of species of Endophragmia auct. with notes on relevant generic names. New Zealand Journal of Botany 17, 139-188.

Kodsueb R, McKenzie EHC, Lumyong S, Hyde KD. 2008 - Diversity of saprobic fungi on Magnoliaceae. Fungal Diversity 30, 37-53.

Marques MFO, Moraes-Júnior VO, Santos SML. 2007 - Fungos conidiais lignícolas em um fragmento de Mata Atlântica, Serra da Jibóia, BA. Revista Brasileira de Biociências 5(2), $1186-1188$.

Marques MFO, Gusmão LFP, Maia LC. 2008 - Riqueza de espécies de fungos conidiais em duas áreas de Mata Atlântica no Morro da Pioneira, Serra da Jibóia, BA, Brasil. Acta Botanica Brasilica 22(4), 954-961.

Matsushima T. 1983 - Matsushima Mycological Memoirs N. 3. Published by the author, Kobe.

Matsushima T. 1987 - Matsushima Mycological Memoirs N. 5. Published by the author, Kobe.

Silva P, Grandi RAP. 2008 - Hyphomycetes sobre o folhedo de Caesalpinia echinata Lam. com duas novas citações para o Brasil. Hoehnea 35(4), 477- 488.

Silvera-Simón C, Mena-Portales J, Gené J, Cano J, Guarro J. 2009 - Repetophragma calongeii sp. nov. and other interesting dematiaceous hyphomycetes from North of Spain. Anales del Jardín Botánico de Madrid 66S1, 33-39. 
Velloso AL, Sampaio EVSB, Pareyn FGC. 2002 - Ecorregiões: Propostas para o bioma Caatinga. APNE - Associação Plantas do Nordeste; Instituto de Conservação Ambiental The Nature Conservancy do Brasil, 1-76.

Wu W, Zhuang W. 2005 - Sporidesmium, Endophragmiella and related genera from China. Fungal Diversity Press, Hong Kong, 1-531. 